\title{
Investigating the Effects of Three Types of Corrective Feedback on the Acquisition of English Wh-question Forms by Iranian EFL Learners
}

\author{
Ehsan Rassaei \\ University of Isfahan, Isfahan, Iran \\ E-mail: ehsanrassaei@yahoo.com \\ Ahmad Moinzadeh \\ University of Isfahan, Isfahan, Iran \\ E-mail: eamoinzad@hotmail.com
}

Received: October 20, $2010 \quad$ Accepted: November 4, 2010 doi:10.5539/elt.v4n2p97

\begin{abstract}
The current research examines the immediate and delayed effects of three types of corrective feedback, namely recasts, metalinguistic feedback, and clarification requests, on the acquisition of English wh-question forms by Iranian EFL learners. To this end, 134 Iranian EFL learners comprising 4 intact classes participated in the study. Learners in 3 intact classes which were designated as feedback groups received feedback during a meaning-focused task, while learners in the control group received no feedback. The results of data analysis revealed the effectiveness of metalinguistic feedback and recasts in both immediate and delayed post-tests. Further inspection of the results revealed that while metalinguistic feedback was more effective than recasts in the immediate post-test, recasts had a more stable and enduring effect, compared with metalinguistic feedback, on learners' performance in the delayed post-test.
\end{abstract}

Keywords: Corrective feedback, Metalinguistic feedback, Recasts, Clarification requests, Implicit feedback, Explicit feedback

\section{Introduction}

A substantial body of research in SLA has been devoted to the role of classroom interaction in second language acquisition. It is believed that during classroom interactions learners receive comprehensible input, opportunities to negotiate for meaning, and opportunities to produce modified output (Gass and Varonis, 1984, 1985b; Swain,1995; Oliver, 1995). Meanwhile, research reveals that exposure to input alone, is not sufficient for learners to acquire the target language items to a high level of proficiency (e.g., Lightbown \& Spada, 1990; Long, 1996; Long \& Robinson, 1998; Norris \& Ortega, 2000).This, especially applies to those features which are semantically redundant, syntactically complex and cognitively demanding. To compensate for learners' failure to notice some aspects of input, researchers have attempted to direct learners' attention to some linguistic features in the input which are problematic for learners. Corrective feedback is among the techniques which are believed to facilitate L2 development by providing learners with both positive and negative evidence ((Long, 1996). Positive evidence provides learners with the correct and target-like structure or what is acceptable in L2, while, negative evidence warns the learners as to what is unacceptable in L2. Corrective feedback is defined as a teacher's move that invites a learner to attend to the grammatical accuracy of the utterance which is produced by the learner (Sheen, 2007). Several studies have investigated the effects of different types of corrective feedback in second language classrooms (Macky, Gass, and McDonough, 2000; Lister and Ranta, 1997; Lyster, 2004; Loewen, 2004; Sheen, 2004). The most comprehensive taxonomy of corrective feedback has been provided by Lyster and Ranta (1997) who classified corrective feedback into six categories. They include: explicit correction, recast, metalinguistic feedback, elicitation, repetition, and clarification request. Among these, the aim of the current study is to investigate and compare the effects of recasts, metalinguistic feedback, \& clarification request, on the development of L2 question forms. The following review of literature is mainly devoted to the three types of corrective feedback, investigated in this study.

\section{Corrective feedback and $L 2$ development}

While various studies have been carried out to inspect the effectiveness of corrective feedback in SLA, there is still debate over what types of corrective feedback is more effective. Among different types of corrective feedback proposed by Lyster and Ranta (1994), explicit correction and metalinguistic feedback are considered as the explicit ones while recast and clarification request are among the implicit types of corrective feedback. The current study addresses recasts, metalinguistic feedback, and clarification requests. These three types of feedback were chosen because they (a) occur relatively frequently during classroom interactions, (b) differ in the level of explicitness, and 
(c) differ in whether they allow self-repair or other-repair.Recasts are among the implicit types of corrective feedback that 'reformulates or expands an ill-formed or incomplete utterance in an unobtrusive way' (Brown, 2007, p.277).Thus, they are argued to be beneficial because they do not disrupt communication and are contingent on learners' errors (Loewen and Nabei, 2007). Research has shown that recast are the most frequently used type of corrective feedback in and out of the classroom (Oliver, 1995; Lyster and Ranta, 1997; Braidi 2002; Sheen, 2004). According to Ellis (1994), recasts create the optimal condition for cognitive comparison because they are assumed to promote noticing of form while a focus on the meaning/message is maintained. Long (1996) in his discussion of the interaction hypothesis maintained that recasts are effective in promoting L2 development because they (as well as other types of interactional feedback) usually occurs during meaning focused activities. In such cases, recasts are believed to provide learners with both comprehensible input and focus on form (Leeman, 2003; Schmidt, 2001). Metalinguistic feedback, in contrast to recasts, is an explicit type of corrective feedback as it provides' comments, information, or questions related to the well-formedness of the student's utterance' (Lyster, 2002, p.405). The advantage of such a corrective feedback is that unlike recasts (and other implicit types of corrective feedback), learners are less likely to misconstrue the feedback intention. However, a caveat for using metalinguistic feedback is that it is obtrusive and disrupts the flow of communication. The third category of corrective feedback considered in the current study is clarification requests which prompt learners to reformulate their own utterance. Like recasts, clarification requests are among implicit types of corrective feedback. But, unlike recasts, clarification requests serve the function of prompting learners to attend to form and asking for clarifying the meaning (Loewen \& Nabei, 2007). Consequently, learners are less likely to notice the correctional purpose of clarification requests. On the other hand, prompting learners to correct themselves may demand processing of language in a deeper level which will in turn result in a more efficient learning.

Several empirical studies investigated the effects of implicit and explicit types of corrective feedback. Carrol and Swain (1993) and Carrol (2001) found that those learners who received explicit corrective feedback outperformed those learners who received implicit error correction. Ellis, Loewen, \& Erlam (2006) also demonstrated that those learners who received metalinguistic feedback outperformed those who received recasts in a delayed post-test, while no difference was observed between the groups in the immediate post-test. Similarly, Lyster (2004) compared the effects of recasts with more explicit types of corrective feedback which he called prompts on French gender assignment and found that prompts were more effective than recasts. Ellis (2009) investigated the effects of recasts and metalinguistic feedback on the acquisition of implicit and explicit knowledge of regular past tense-ed. The results of this study indicated a distinct advantage for the group that received metalinguistic feedback. Other studies, in contrast, reported the beneficial effects of implicit types of feedback such as recasts and clarification requests. Mackey and Philp (1998), for example, reported the beneficial effects of recasts on learning with respect to L2 learners' acquisition of question forms. Iwashita (2003) indicated a relationship between being exposed to implicit types of corrective feedback and in particular recasts and measurable gains in the acquisition of two grammatical structures in L2 Japanese. Sanz and Morgan-Short (2004) also found that explicit types of corrective feedback may confer no additional advantage over implicit corrective feedback.

\section{Research questions}

A review of previous studies on corrective feedback reveals mixed results with some studies in favor of explicit corrective feedback and still others in favor of implicit corrective feedback. Furthermore, to the best of the authors' knowledge, no such study has been yet performed within Iranian socio-cultural context. Thus, in order to investigate the immediate and delayed effects of recasts, metalinguistic feedback and clarification requests on the acquisition of English wh-question forms by Iranian EFL learners of English, the following research questions were formulated:

1).Do recasts, metalinguistic feedback and clarification requests have differential effects on the acquisition of English wh-question forms?

2).Is there any difference among the three types of corrective feedback mentioned above in terms of their immediate and delayed effects?

\section{Method}

\subsection{Design}

The study employed a quasi-experimental research design with a pre-test, treatment, post-test, delayed post-test design using intact EFL classrooms. Learners in three intact classes formed experimental groups and received treatment, while the fourth group served as control group.

\subsection{Participants}

The participants in this study were 134 Iranian EFL learners ( 75 females and 59 males), all university students with a mean age of 20.2 years $(\mathrm{SD}=1.2)$. They were learning English in a language teaching institute in an urbane area. 
They had received formal classroom instruction in English for five to seven years in Iran. None of them had stayed in an English speaking country for more than two weeks. Because of institutional constraints, it was not possible to assign students randomly to experimental groups, thus making it necessary to work with intact groups. Four intact classes were chosen. The learners' proficiency levels in this institute were determined by a simulated TOEFL exam and also an interview. There were 32 learners ( 17 females, 15 males) in the control class (hereafter control group), 35 learners (19 females, 16 males) in one treatment class who received recasts as corrective feedback (hereafter recast group), 34 participants (20 females and 14 males) in the second treatment group who received metalinguistic corrective feedback (hereafter mealinguistic group) and 33 learners (19 females and 14 males) in the third experimental group who received clarification requests as corrective feedback (hereafter clarification group). Beside the researcher, 2 EFL teachers were invited to the study to serve as interlocutor along with the researcher during treatment sessions (henceforth interlocutors). Prior to the study, the researcher met other interlocutors several times and informed them fully about the research objectives and procedures.

\subsection{Target structure}

The target structure used in this study is English wh-question forms. Several syntactic operations are involved in wh-question formation such as wh fronting, auxiliary-verb inversion, Do-support. This target form was chosen for several reasons. First, they are easy to elicit and score during meaning-focused tasks. Further motivation for choosing wh-question forms as target structures for this study mainly comes from recent studies regarding the availability of features of universal grammar in second language acquisition. It has been assumed that some aspects of universal grammar which are not present in the grammar of L1 will not be available for L2 grammar construction and thus pose difficulty for L2 learners (see Hawkins \& Chan, 1997; Tsimpli, 2003; Hawkins \& Hattory, 2006 for a review). Based on this assumption, Persian L2 learners of English have difficulty with the acquisition of wh-question forms (the detailed discussion of the syntactic mechanisms responsible for such difficulty is beyond the scope of this paper).

\subsection{Operationalizations}

\subsubsection{Recasts}

Recasts were operationalized as a teacher's reformulation of a student's erroneous sentence. During the treatments, the interlocutors reformulated the participants question forms. The following examples indicate how recasts were operationalized:

Example 1,

Student: Where she go?

Interlocutor: Where does she go?

Example 2,

Student: When you come back?

Teacher: When do you come back?

The words in bold-face show that the interlocutors phonetically emphasized the corrected parts of the learners' utterances.

\subsubsection{Metalinguistic error correction}

Metalinguistic correction was operationalized as teachers' provision of grammatical explanations regarding the target structure. Besides providing grammatical explanation, the correct forms of the participants' ungrammatical utterances were also pointed out. An example of metalinguistic correction used in the study is given:

Example 3,

Student: Where he is study?

Teacher: Um, can you thing about your grammar?...you need to use -ing form after auxiliary verbs such as am, is, are to indicate present continuous. You also need to reverse the place of auxiliary and subject. Where is he studying?

\subsubsection{Clarification request}

As another category of corrective feedback, clarification requests were operationalized as those prompts by teachers which invite a learner to self-repair. The following example represents a clarification request in the study:

Example 4,

Learner: What the man do? 
Interlocutor: Would you repeat your sentence?

\subsection{Corrective feedback treatment instruments and procedures}

This study used 'spot the difference task' (Mackey, 1994) in order to elicit learners' knowledge of question forms during treatment sessions. This task consisted of two sets of pictures with one set containing slightly different pictures. Learners were provided with one set of pictures while an interlocutor held the other one. Learners were told that there are some differences between your cards and those of the interlocutor and you should find these differences by asking questions regarding what the pictures depict. Each set of pictures contained 10 pictures. The learners were also told that for each picture just one difference should be found. Learners in each group were then assigned to groups of three and were asked to discuss the possible differences which may exist between their cards and those of the interlocutor for 15 minutes. Each group was then assigned to one of the three interlocutors. During the treatment sessions members in each group ask questions in turn. In order to elicit the desired response, the interlocutors provided the learners with some hints regarding the differences between the two sets of cards. The task for each group continued until a total of 15 corrective feedbacks were provided to the group members. During the treatment sessions, when learners either failed to produce a wh-question form or an ungrammatical form, they received feedback according to their group designation. The following example indicates how spot the difference task was performed to elicit learners' production. The example also shows how the learner was provided with a recast.

Interlocutor: now, think about the boy, he is doing...

learner: what the boy doing?

interlocutor: what is the boy doing? (the learner was provided with a recast)

Learner: yea, what is the boy doing?

interlocutor: in my picture, he is reading a book

learner: in my picture he is writing (something), (one difference was found).

Two treatment sessions were held for each group during a week. All treatment sessions were videotaped and afterwards inspected by the researcher to ensure the uniformity of treatment procedures across groups and also inter-interlocutor and intra-interlocutor consistencies. No serious flaw or inconsistency which may threat the validity of the results was found.

\subsection{Testing instruments and procedures}

In order to measure learning gains which might have occurred as a result of the treatment, an untimed grammaticality judgment test was assigned to learners once as a pretest and subsequently as a posttest and also as a delayed posttest. The test consisted of 30 items targeting wh-question forms for which learners received feedback and 15 distracters (targeted at negation, past tense -ed, comparative -er, plural -s). The pretest was administered to learners one day before the treatments began. The posttest and delayed posttest were administered one day after the treatments finished and 10 days later respectively. The distracters were incorporated in order to avoid making learners sensitive to the target structures in the pretest. Half of the questions in the test were grammatical and half were ungrammatical. The items in the three tests were the same but with different order. The test was a paper and pencil test. For each correct answer one point was assigned to the learners.

\subsection{Analysis}

In order to answer the research questions posed in the current study, the raw scores for all grammaticality judgment tests (pre-test, post-test, and delayed post-test) were obtained. One-way ANOVA was then performed on the pretest scores to examine any difference among the groups before the study. To investigate possible learning gains caused by treatment materials among the groups over time, a two-way repeated measures ANOVA was performed with total scores as dependent variable and with time (pre-test, post-test 1, post-test 2) and corrective feedback treatment as independent variables. Post hoc analyses were performed when an ANOVA was significant. An alpha level of .05 was set. SPSS 16 was used to perform the analyses.

\section{Results}

Table 1 displays the results of descriptive statistics for pretest, posttest and also delayed posttest.

To establish whether the differences between individuals' scores in the pretest were significant, a one-way ANOVA was performed on the pre-test scores. Table 2 shows the results. No statistically significant difference was observed in grammaticality judgment test among the four groups: $F(3,130)=.160$

In order to answer the research questions posed in this study, a two-way repeated measures ANOVA was performed with total scores as dependent variable and with time (pre-test, post-test, delayed post-test) and corrective feedback 
treatments as independent variables. Table 3 shows the results of the analysis. As table 3 displays, there is a statistically significant effect for corrective feedback treatment, $F(3,130)=15.79$. This suggests that corrective feedback had a significant effect on learners' performance. There was also a significant effect for time suggesting that there was a change in learners' scores across the three time intervals, $F(2,131)=94.06$.

Given that there were longitudinal gains for all groups over time, the crucial analysis is time*corrective feedback interaction. As table 3 displays, there was a significant time* treatment interaction, indicating that the groups performed differently from each other over time: $F(6,129)=14.09$.

One-way ANOVAs revealed significant group differences in both post-test $1, F(3,130)=33.3$, and post-test $2, F(3$, $130)=15.69$. Table 4 and 5 display the results of one-way ANOVA for post-test and delayed-post-test. The results of Tukey's post-hoc comparisons for post-test scores revealed significant differences between recast and metalinguisitc groups, recast and clarification groups, metalinguisitic and clarification groups, recast and control groups and finally metalinguisitc and control groups. No statistically significant difference, on the other hand, was observed between clarification and control groups.

The Tukey's post-hoc analysis of delayed post-test results revealed another story. In the delayed post-test, no statistically significant difference was observed between the metalinguistic and recast groups. Significant differences were observed among metalinguistic and recast groups on one hand and control and clarification groups on the other hand.

Figure1 provides a visual representation of learners' performance in three testing periods across four treatment groups. The figure shows that there is a sharp decline in metalinguistic group's test performance from post-test to delayed post-test resulting in no significant difference between metalinguisitc and recast groups.

\section{Discussion and conclusion}

The current study investigated the effects of three types of corrective feedback on the acquisition of English question forms across three time intervals. The results of data analysis revealed that only recasts and metalinguistic feedback had a significant effect on learners' performance on the post-test. In other words, no significant difference was observed between control and clarification groups. Such a finding can be explained with regard to the kind of linguistic evidence which learners were exposed to. Metalinguistic feedback provides learners with explicit negative evidence, while, learners are provided with both implicit negative evidence and positive evidence through recasts. Clarification requests, on the other hand, just provide learners with implicit negative evidence. In the light of the above evidence, it can be argued that explicit negative evidence seems crucial for language development and is superior to positive evidence per se. Although, recast group performed significantly better than clarification and control groups in the post-test, metalinguistic group performed significantly better than recast group lending support to the superiority of metalinguistic feedback over recasts. Concerning the delayed post-test, while a statistically significant difference is still observed between recast and metalinguistic groups on one hand and control and clarification groups on the other, the significant difference between recast and metalinguistic groups was blurred. In other words, the metalinguistic group didn't perform significantly better than the recast group in delayed post-test. This means that that the effect of recasts was more enduring than that of metalinguistic feedback. In the light of the argument above, the answers to research questions posed in the current study are straightforward: concerning research question 1, the results presented in the preceding section show that among the three types of corrective feedback investigated in the current study, metalinguistic feedback and recasts lead to an increase in learners' performance in both post-test and delayed post-test. Clarification requests on the other hand had no significant effect on learners' performance. Beside the argument above, concerning the kind of evidence which learners are exposed to, the effectiveness of metalinguistic feedback in the current study can be explained with regards to the role and importance of attention in L2 acquisition. According to Gass \& Macky (2000) attention mediates between input and intake. Similarly, Schmidt (2001) claims that attention "is necessary in order to understand virtually every aspect of second language acquisition" (p. 1).The positive effects of metalinguistic feedback in both posttest and delayed posttest is consistent with the above view that attention plays an important role in L2 acquisition. Thus, metalinguistic feedback prompted learners to pay more attention to the errors they commit and also to the metalinguistic information provided by interlocutors. Further proof to the facilitative effect of attention in the acquisition of target forms in this study is the superiority of recasts over clarification requests and ineffectiveness of clarification requests in both tests. In this regard, clarification requests are among the most implicit types of corrective feedback (Lyster and Ranta, 1997) and thus provide no explicit indication to the learner that an error has been committed at least in the way it was operationalized in this study. Metalinguisitic feedback, in contrast to clarification requests and recasts, is the most explicit and proved to be the most effective in both posttest and delayed posttest. The incorporation of some kind of explicit instruction into language teaching classrooms has 
received much support from many researchers. There is consensus among language teaching researchers and practitioners that if the goal of L2 classroom activities is to develop both accuracy and fluency, form-focused activities including explicit error correction must be integrated with meaningful activities. Concerning the second research question posed in the current study, the results indicated that in the post-test, metalinguistic group outperform other groups including recast group (although recast group outperformed clarification and control groups as well). However, in the delayed post-test, although both recast and metalinguistic groups outperformed clarification and control groups, no statistically significant difference was observed between recast and metalinguistic groups. Such a finding may suggest that implicit types of feedback such as recasts may have a more enduring effect than explicit ones such as metalinguistic feedback. In other words, it can be argued that while metalinguistic corrective feedback is more effective in short run, recasts are more effective in long run. The results of this study is ,then, in contrast with Ellis, Loewen, and Erlam (2006) who found no difference between recasts and metalinguistic groups in immediate posttest but reported the superiority of metalinguistic over recasts group in the delayed posttest. The lasting effect of recasts compared with metalinguistic feedback, found in this study, can be explained with regard to the deeper level of processing that recasts entails, at least in the way they were operationalized in the current study compared with matalinguistic feedback. Recent research into measurement of implicit versus explicit L2 knowledge suggests that tests which allow unlimited time to learners and encourage them to focus on discrete grammatical points may draw on learners' explicit L2 knowledge (Han, 2000; Ellis, 2004). It can, then, be argued that since recasts are implicit, gaining metalinguistic information from recasts which is needed for performance in an untimed grammaticality judgment test entails a deeper level of processing. In other words, when learners are provided with recasts they have to acquire the rule inductively which in turn leads to higher level of processing. On the other hand, metalinguistis group were provided with metalinguistic information plus an example of the correct form of the structure, letting learners to get the rule deductively.

\section{References}

Ammar, A. \& Spada, N. ( 2006). One size fits all? Recasts, prompts, and L2 learning. Studies in L2 Acquisition, 28, 543-574.

Birmingham, D. L. (1974). Situational and personality factors in conformity. Doctoral Dissertation Saint Louise University. Dissertation Abstracts International, 35, 2421B. (University Microfilm No. 74-24024).

Braidi, S.M. (2002). Reexamining the role of recasts in native-speaker/ nonnative-speaker interaction. Language Learning, 52, 1-42.

Brown, D. B. (2007). Principles of Language Learning and Teaching. (6 ${ }^{\text {th }}$ ed.). NY: Pearson.

Carrol, S. (2001). Input and Evidence: The Raw Material of Second Language Acquisition. Amsterdam: John Benjamins.

Carroll, S., \& Swain, M. (1993). Explicit and implicit negative feedback: An empirical study of the learning of linguistic generalizations. Study in Second Language Acquisition, 15, 357-386.

Chapelle, C. \& Roberts. C. (1986). Ambiguity tolerance and field independence as predictors of proficiency in English as a second language. Language Learning, 36, 27-45.

DeKeyser, R. (1993). The effect of error correction on L2 grammar knowledge and oral proficiency. The Modern Language Journal, 77, 501-514.

Davis, J.K. (1991). Educational implications of field dependence/independence. In S. Wapner, \& J. Demick (Eds.), Field Dependence-independence: Cognitive Style Across the Life Span. Hillsdale, NJ: Lawrence Erlbaum Associates.

Doughty, C. \& Varela, E. (1998). Communicative focus on form. In Doughty, C. and Williams, J. (Eds). Focus on Form in Classroom Second Language Acquisition (PP. 114-138). Cambridge: Cambridge University Press.

Egi, T., (2007). Recasts, learner's interpretations, and L2 development. In A. Mackey (Eds.), Conversational interaction in second language acquisition: a collection of empirical studies (pp. 249-267). Oxford: Oxford University Press.

Ellis, R. (1994). The study of second language acquisition. Oxford: Oxford University Press.

Ellis, R. (2001). Non-reciprocal tasks, comprehension, and second language acquisition. In M. Bygate, P. Skehan, and M. Swain (Eds.), Researching Pedagogic Tasks: Second Language Learning, Teaching, and Testing. Harlow: Pearson.

Ellis, R. (2004). The definition and measurement of L2 explicit knowledge. Language Learning, 54, 227-275. 
Ellis, R. (2006). Researching the effects of form-focused instruction on L2 acquisition. AILA Review, 19, 18-41.

Ellis, R. (2009). Implicit and explicit learning, knowledge and instruction. In Ellis et al, (Eds.), Implicit and Explicit Knowledge in Second Language Learning, Testing and Teaching (pp. 31-64). Bristol: Short Run Press Ltd.

Ellis, R. and Sheen, Y. (2006). Re-examining the role of recasts in second language acquisition. Studies in Second Language Acquisition, 28, 575-600.

Ellis, R., Loewen, S. \& Erlam, R. (2006). Implicit and explicit corrective feedback and the acquisition of L2 grammar. Studies in Second Language Acquisition, 28, 339-68.

Gass, S. M. \& Varonis, E. (1984). The effect of familiarity on the comprehensibility of nonnative speech. Language Learning, 34, 65-89.

Gass, S. M. \& Varonis, E. (1985b). Variation in native speaker speech modification to nonnative speakers. Studies in Second Language Acquisition, 7, 37-58.

Gass, S. (1988a). Integrating research areas: a framework for second language studies. Applied Linguistics, 9, 198-217.

Han, Y. (2000). Grammaticality judgment tests: How reliable and valid are they? Applied Language Learning, 11, 177-204.

Han, Z.-H. (2002b). A study of the impact of recasts on tense consistency in L2 output. TESOL Quarterly, 36, 543-72.

Havaranek, G. \& Cesnik, G. (2001). Factors affecting the success of feedback, in S. Foster-Cohen and A. Nizeorodzew (Eds.). EUROSLA Yearbook, Volume I. Amsterdam: John Benjamins.

Hawkins, Roger \& Cecilia Yuet-hung Chan. (1997). "The partial availability of Universal Grammar in second language acquisition: the 'failed functional features hypothesis'”. Second Language Research 13, 187-226.

Hawkins, R. \& Hattori, H. (2006). 'Interpretation of English multiple wh-questions by Japanese speakers: a missing uninterpretable feature account.' Second Language Research 22, 269-301.

Iwashita, N. (2003) Negative feedback and positive evidence in task-based interaction: Different effects onL2 development. Studies in Second Language Acquisition, 25, 1-36.

Leeman, J. (2003). Recasts and L2 development: beyond negative evidence. Studies in Second Language Acquisition, 25, 37-63.

Lightbown, P., \& Spada, N. (1990). Focus on form and corrective feedback in communicative language teaching: Effect on second language learning. Studies in Second Language Acquisition, 12, 429-448.

Loewen, S. (2004). Uptake in incidental focus on form in meaning-focused ESL lessons. Language Learning, 54, 153-188.

Loewen, S. \& Nabei, T. (2007). Measuring the effects of oral corrective feedback on L2 knowledge. In A. Mackey (Eds.), Conversational Interaction in Second Language Acquisition: A Collection of Empirical Studies (pp.361-376). Oxford: Oxford University Press.

Loewen, S. \& Philp, J. (2006). Recasts in adult English L2 classroom: Characteristics, explicitness, and effectiveness. The Modern Language Journal, 90 (4), 536-556.

Long, M. (1996). The role of the linguistic environment in second language acquisition. In W. C. Ritchie \& T. K. Bhatia (Eds.), Handbook of Second Language Acquisition (pp. 413-468). San Diego, CA: Academic Press.

Long, M., Inagaki, S., \& Ortega, L. (1998). The role of implicit negative feedback in SLA: Models and recasts in Japanese and Spanish. Modern Language Journal, 82, 357-371.

Long, M. H., \& Robinson, P. (1998). Focus on form: Theory, research, and practice. In C. Doughty \& J. Williams (Eds.), Focus on Form in Classroom Second Language Acquisition (pp. 15-41). New York: Cambridge University Press.

Lyster, R. (2002). The importance of differentiating negotiation of form and meaning in classroom interaction. In Burmeister, P., Piske, T. and Rohde, A., (Eds.), An Integrated View of Language Development: Papers in Honor of Henning Wode. Wissen-schaftlicher Verlag Trier, 381-97.

Lyster, R. (2004). Different effects of prompts and recasts in form-focused instruction. Studies in Second Language Acquisition, 26, 399-432.

Lyster, R., \& Ranta, L. (1997). Corrective feedback and learner uptake: Negotiation of form in communicative 
classrooms. Studies in Second Language Acquisition, 20, 37-66.

Mackey, A. (1994). Using Communicative Tasks to Target Grammatical Structures: a Handbook of Tasks and Instructions for Their Use. Sydney : Language Acquisition Research Center.

Mackey, A., \& Philp, J. (1998). Conversational interaction and second language development: Recasts, responses, and red herrings? Modern Language Journal, 82, 338-356.

Mackey, A., S. Gass, and K. McDonough. (2000). How do learners perceive interaction feedback? Studies in Second Language Acquisition, 22, 471-498.

McDonough, K. (2005). Identifying the impact of negative feedback and learners' responses on ESL question development. Studies in Second Language Acquisition, 27, 79-103.

Naiman, N., Frohlich, M., Stern, H., \& Todesco, A. (1987). The good language learner, Research in education series, No. 7, Toronto: the Ontario institute for studies in education.

Norris, J. M., \& Ortega, L. (2000). Effectiveness of L2 instruction: A research synthesis and quantitative meta-analysis. Language Learning, 50, 417-528.

Oliver, R. (1995). Negative Feedback in Child NS-NNS Conversation. Studies in Second Language Acquisition, 17, 459-481.

Philp, J. (2003). Constraints on "noticing the gap": Non-native speakers' noticing of recasts in NSNNS interaction. Studies in Second Language Acquisition, 25, 99-126.

Pienemann, M. (1989). Is language teachable? Psycholinguistic experiments and hypotheses. Applied Linguistics, 10, $52-79$.

Pienemann, M. (1998). Language Processing and Second Language Development: Processability Theory. Amsterdam: Benjamins.

Ranta, L. (2002). The role of learners' language analytic ability in the communicative classroom. In P. Robinson (Eds.), Individual differences and instructed language learning .Amsterdam: John Benjamins.

Robinson, P. (1995). Attention, memory, and the "noticing" hypothesis. Language Learning, 45, 283-331.

Robinson, P. (1996). Learning simple and complex second language rules under implicit, incidental, rule-search, and structured conditions. Studies in Second Language Acquisition, 18, 27-67.

Sanz, C. \& Morgan-Short, K. (2004). Positive evidence versus explicit rule presentation and explicit negative feedback: A computer-assisted study. Language Learning, 54, 35-78.

Schmidt, R. (1990). The role of consciousness in second language learning. Applied Linguistics, 11, 206-226.

Schmidt, R. (1995). Consciousness and foreign language learning: A tutorial on the role of attention and awareness in learning. In R. Schmidt (Eds.), Attention and Awareness in Foreign Language Learning (pp. 1-63). Honolulu: University of Hawai' $\mathrm{i}$ Press.

Schmidt, R. (2001). Attention. In P. Robinson (Eds.), Cognition and second language instruction (pp. 3-32). New York: Cambridge University Press.

Sheen, Y. (2004). Corrective feedback and learner uptake in communicative classrooms across instructional settings. Language Teaching Research, 8, 263-300.

Sheen, Y. (2006). Exploring the relationship between characteristics of recasts and learner uptake. Language Teaching Research, 10, 361-392.

Sheen, Y. (2007). The effects of corrective feedback, language aptitude, and learner attitudes on the acquisition of English articles. In A. Mackey (Eds.), Conversational Interaction in Second Language Acquisition: A Collection of Empirical Studies (pp. 301-322). Oxford: Oxford University Press.

Spada, N. \& Lightbown, P. (1993). Instruction and the development of questions in L2 classrooms. Studies in Second Language Acquisition. 15, 205-224.

Spada, N., \& Lightbown, P. (1999). Instruction, first language influence, and developmental readiness in second language acquisition. Modern Language Journal, 83, 1-22.

Swain, M. (1995). Three functions of output in second language learning. In G. Cook \& B. Seidlhofer (Eds.), Principles and Practice in the Study of Language: Studies in Honour of H.G. Widdowson (pp. 125-144). Oxford: Oxford University Press. 
Tomlin, R., \& Villa, V. (1994). Attention in cognitive science and second language acquisition. Studies in Second Language Acquisition, 16, 183-203.

Trofimovich, P., Ammar, A, \& Gatbonton, E. (2007). How effective are recasts? The role of attention, memory, and analytic ability. In A. Macky (Eds.), Conversational interaction in second language acquisition: a collection of empirical studies (pp. 171-195). Oxford, Oxford University Press.

Truscott, J. (1996). The case against grammar correction in L2 writing classes. Language Learning, 46, 327-369.

Tsimpli, I.M., (2003). Clitics and Determiners in L2 Greek. Proceedings of Generative Approaches to Second Language Acquisition. Cascadilla Press.

White, L. (1991). Adverb placement in L2 acquisition: some effects of positive and negative evidence in the classroom. Second Language Research, 7, 133-161.

Table 1. Descriptive statistics for pretest, posttest, and delayed posttest.

\begin{tabular}{|l|l|l|l|l|}
\hline Test & Group & Mean & SD & N \\
\hline Pre & Recasts & 13.88 & 1.15 & 35 \\
\hline & Metalinguistic & 13.79 & .94 & 34 \\
\hline & Clarification & 13.72 & .98 & 33 \\
\hline & Control & 13.75 & 1.01 & 32 \\
\hline Post & Recasts & 15.17 & .95 & 35 \\
\hline & Metalinguistic & 15.97 & .71 & 34 \\
\hline & Clarification & 14.33 & .85 & 33 \\
\hline & Control & 13.93 & 1.07 & 32 \\
\hline Delayed & Recasts & 15.31 & 1.02 & 35 \\
\hline & Metalinguistic & 15.44 & .95 & 34 \\
\hline & Clarification & 14.36 & 1.05 & 33 \\
\hline & Control & 13.96 & 1.09 & 32 \\
\hline
\end{tabular}

Table 2. One-way ANOVA for pretest scores

\begin{tabular}{|l|c|l|l|l|l|}
\hline & Sum of Squares & df & Mean squares & F & Sig \\
\hline Between Groups & .502 & 3 & .167 & .160 & .923 \\
\hline Within groups & 135.647 & 130 & 1.043 & & \\
\hline Total & 136.149 & 133 & & & \\
\hline
\end{tabular}

Table 3. Repeated-measures ANOVA across the four treatments and the three testing periods

\begin{tabular}{llccc}
\hline \multirow{3}{*}{ Between learners } & Source & Df & $F$ & $p$ \\
& Corrective feedback treatment (CFT) & 3 & 15.79 & $<.001$ \\
& Error & 130 & & \\
Within learners & Time & 2 & 94.06 & $<.001$ \\
& Time* CFT & 6 & 14.09 & $<.001$ \\
& Error & 258 & & \\
\hline
\end{tabular}


Table 4. One-way ANOVA for posttest scores

\begin{tabular}{|l|l|l|l|l|r|}
\hline & Sum of squares & $\mathrm{df}$ & Mean square & $\mathrm{F}$ & Sig \\
\hline Between groups & 81.69 & 3 & 27.23 & 33.03 & .000 \\
\hline Within groups & 107.15 & 130 & .73 & & \\
\hline Total & 188.84 & 133 & & & \\
\hline
\end{tabular}

Table 5. One-way ANOVA for delayed posttest scores

\begin{tabular}{|l|l|l|l|l|l|}
\hline & Sum of squares & df & Mean square & F & Sig \\
\hline Between & 51.61 & 3 & 17.20 & 15.69 & .000 \\
\hline Within & 142.53 & 130 & 1.09 & & \\
\hline Total & 194.149 & 133 & & & \\
\hline
\end{tabular}
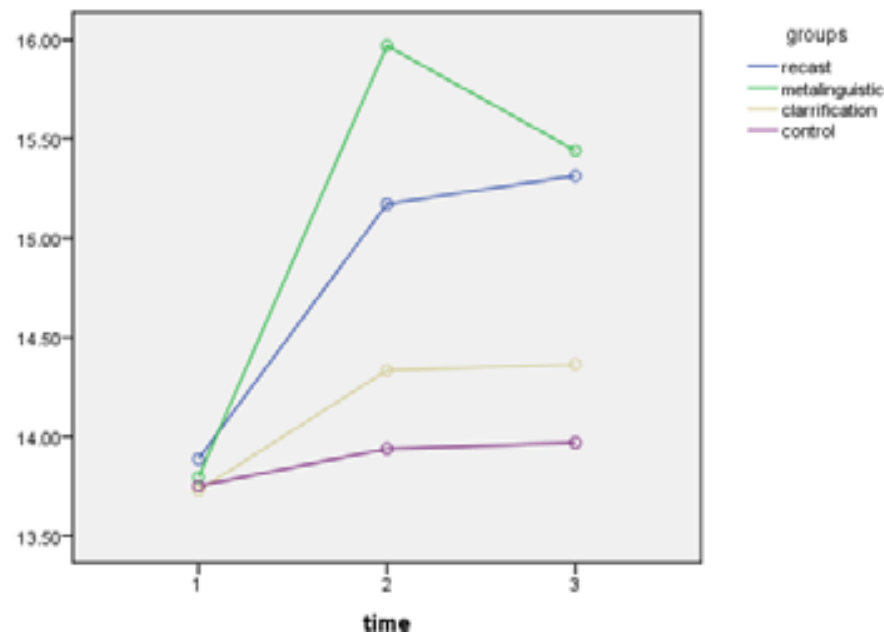

Figure1. Mean total performance across time 